DOI https://doi.org/10.30525/978-9934-26-148-0-5

\title{
ВІДНОСИНИ СОКРАТА І АФІНСЬКОЇ ДЕРЖАВИ В ІНТЕРПРЕТАЦІЇ КАРЛА ЯСПЕРСА
}

\author{
Калкатиніч О. Д. \\ здобувач другого (магістерського) рівня вищої освіти ПЗВО \\ «Міжнародний класичний університет імені Пилипа Орлика»
}

\section{Мірошкіна Н. В.}

кандидат філософських наук, дочент кафедри права ПЗВО «Міжнародний класичний університет імені Пилипа Орлика» м. Миколаїв, Україна

Карл Ясперс входить до числа найвпливовіших філософів XX століття. Як представник екзистенціалізму, найважливішою цінністю він визнавав свободу. Він дуже скептично ставився до мажоритарної демократії, вважаючи, що демократією повинна керувати інтелектуальна еліта, велику увагу приділяв духовним факторам у розвитку людства, а також особистостям, з якими пов'язане становлення цивілізації. Особистість Сократа $\epsilon$ однією з основних фігур осьового часу, який він виділив - (періоду з 800 р до н.е. по 200 г. до н.е.) - часу, коли формується тип людини, який існує і донині. У дослідженні, присвяченому особистості Сократа, німецький філософ чималу увагу приділяв проблемі відносин великого афінського філософа і держави. Доля Сократа дозволяє нам зрозуміти стосунки між людиною та державою в древніх Афінах на прикладі окремої особистості, особистості неординарної і великої, хоча більшість афінян, напевно, так не вважали.

Усе вчення Сократа викладене в бесідах 3 учнями та іншими людьми - громадянами його рідного міста Афіни. Він ставив питання i підводив людей до висновків. Сократ ніколи не наполягав, що сам знає відповіді на питання. Він не заснував ані школи, ані партії, не вів пропаганди. Він не мав ані програми державних реформ, ані навіть системи знань. Але він вів до істини, яка об'єднує людей. К. Ясперс підкреслював, що Сократ звертався до публіки, до кожного, а не до народних зборів. Цей стан німецький філософ підкріплює цитатою 3 платонівської «Апології Сократа», де сам Сократ підкреслює, що звертається до всіх приватним чином [1, с. 41]. Він обгрунтовує це тим, що той, хто чесно і відкрито протистоїть натовпу, той ризикує своїм життям, тож потрібно звертатися до приватних осіб. Напевно, такий підхід був викликаний критичним ставленням Сократа до демократії як 
до форми правління, яка вже за його життя почала вироджуватися у владу натовпу - охлократію. К. Ясперс вважав, що трактувати звернення Сократа до приватних осіб потрібно ширше - хибність будь-якого становища, незалежно від того, яким є правління - демократичним, аристократичним або тиранічним, долається не великими політичними діями, а тим, як індивід вихований. Виховувати себе треба через набуття знання. Знання саме по собі є чеснотою. Той, кому вдалося стати справжньою людиною, стане і справжнім громадянином. Якості справжнього громадянина визначаються якостями справжньої людини, а не його успіхами в державі. Сократ дуже серйозно ставився до своїх цивільних обов'язків: він вірив в традиційних богів, брав участь в релігійних церемоніях i громадських святах, поважав авторитет провісників (дельфійського оракула), брав участь в народних зборах і за жеребом обирався головуючим, проходив підготовку як ополченець, був учасником боїв, як громадянин він не нехтував і своїми можливостями (наприклад, отримував безкоштовний хліб, який надіслав єгипетський фараон на знак вдячності Афінам за військову допомогу). Сократ був вірний законам, підкреслює К. Ясперс. Сократ відмовився навпаки закону втекти 3 в’язниці, оскільки вважав, що закон залишається законом навіть тоді, коли він несправедливий [2, с. 204].

Сократ залишається громадянином свого поліса навіть тоді, коли поліс вирішив його несправедливо знищити. Він залишається вірним своєму принципові - зазнавати несправедливість краще, ніж їі творити. Нещастя, яке його спіткало, не поставило питання про те, чи потребує бог виправдання. Смерть він приймає смиренно. Він живе своїм духовним життям, відповідно до вимог свого «даймонія», внутрішнього голосу, який забороняє йому втручатися в політику. Єдиною цінністю для філософа залишається життя, що протікає відповідно до встановленої істини, яка прояснюється в мисленні. Якщо людині потрібні гарантії, релігійне знання про кінець речей, Бога і безсмертя - то Сократ не відповість на ці питання - людський розум може лише зробити висновок про наявність добра. І тут згадується: «Я знаю тільки те, що я нічого не знаю, отже, я нічому не зможу вас навчити, я тільки можу допомогти світлу істини народитися в ваших серцях». К. Ясперс називає таке незнання позитивним, оскільки воно дозволяє людині залишатися самою собою і містить все ж таки знання про істину, оскільки воно не суперечить усвідомленню добра як істини. I лише від людини залежить, що вона творець добра. Сократ каже на суді, що його «даймоній», внутрішній демон, як переклав це слово К. Ясперс, не стримував його, коли він йшов до суду, не зупиняв його коли він виголошував промову. А цей внутрішній голос був, на думку великого афінського філософа, божественним. Тож те, що робив і говорив Сократ в суді, є добро. 
К. Ясперс вказує на нерозуміння Сократа афінським суспільством. Він посилається на комедію Аристофана "Хмари”, в якій зображений певний Сократ, якого і в народі почали пов'язувати 3 реальним Сократом. Сократ Аристофана має справу з небесними і підземними явищами, відкидає традиційних богів і ставить на їх місце повітря i хмари, навчає мистецтву добуватися успіху, в тому числі і в справах негідних, та отримує за це гроші. Надалі до цього додали звинувачення в тому, що Сократ спокушав до неробства, для обгрунтування свого злочинного вчення вдавався до тлумачення поетів, тримав біля себе учнів, серед яких такі вороги народу, як тирани Алківіад і Крітій. К. Ясперс пояснює ці звинувачення невіглаством афінського суспільства, що сплутало Сократа, який подолав вчення софістів, 3 самими софістами. Новий спосіб мислення, який запропонував Сократ, був неприпустимий: він ставив питання з фундаментальних для суспільства проблем, але не пропонував відповідей. Збентеження, які викликали такі питання, призводило до ненависті до Сократа. Люди вважали, що філософ насміхається над ними. Сократ був звинувачений в порушенні законів, невірі в богів своєї батьківщини, розбещенні молоді та ставленні до віри як до нового роду демонічного.

Демократія звинуватила Сократа в тому, що молоді люди після спілкування з ним стають тиранами. Але і в період «Правління тридцяти тиранів» Сократ зазнавав серйозної небезпеки. Тиранів дратували його пошуки справедливості, істини і вимоги доброчесного життя. В той момент від страти його врятувало лише вигнання тиранів. Цікаво, що афінська держава i за тиранічного, і за демократичного режимів приблизно однаково ставилась до Сократа, наголошує К. Ясперс.

Традиційно вважається, що Сократа вбила афінська демократія. Сократа судили за традиційною процедурою судом присяжних у складі 501 судді. Він був визнаний винним 281 голосами проти 220. Коли судді, відповідно до традиції, запитали, яке покарання він хоче отримати, Сократ відповів, що він зробив для міста стільки, що заслуговує на найвищу нагороду - довічних безкоштовних обідів за рахунок міста. Ця відповідь виглядала як глузування з суддів і Сократ був засуджений на смерть. К. Ясперс підкреслює, що саме смерть Сократа сформувала його образ як мученика філософії і визначила його подальший вплив. Однак він показує, що сам Сократ сприяв винесенню смертного вироку, бажав власної смерті. Але німецький філософ вважає, що було б невірно говорити, що смерть Сократа - це не судове вбивство, а судове самогубство. Він вважає, що «така думка, що визнає винним убитого замість вбивць, недооцінює те, що для Сократа божественне покликання сприяти правді було несумісним 3 пристосуванням до неправди, що увійшла у звичай. Він був справжнім мучеником, тобто свідком істини». Це і $є$ причина, чому Сократ відкинув можливість втекти, хоча його й не 
охороняли суворо. Зрозуміти сенс вчинку Сократа, пише сучасний філософ, можна тільки виходячи 3 сократичного мислення. Лише цей тип мислення дозволяє без фальші діяти і вмирати.

К. Ясперс надає оцінку вироку Сократа Гегелем: Афіни мали рацію, бо відстоювали свою сутність, Сократ мав рацію, оскільки він сповіщав нову епоху, яка цю сутність руйнувала. К. Ясперс не поділяє такого підходу. Він вважає, що така абсолютизація конфлікту невідповідна значенню Сократа. Трансформація духу епохи не означає правоти епохи i не приміряє різні правди. Скоєне буде піддане вищому суду (i це пише представник атеїстичної філософії) [2, с. 209]. Істинне і благе, як i помилкове і нице, не можуть бути закриті маскою трагічного. Філософ переконаний, що невігластво афінського суспільства не знімає з нього і афінського держави відповідальності за смерть Сократа. Смерть Сократа в юридичному сенсі ще й розкриває цинізм, лукавство і лицемірство афінського суду - його вирок не $є$ остаточним, це вирок тільки формально. За людиною залишається вибір. Сократ помер не тому що так вирішила афінська демократична держава, а тому, що таким був його вибір. Абсолютно усвідомлено, він зробив свій вибір сам. Для того, щоб дати вірну оцінку вибору великого філософа, пише К. Ясперс, i зрозуміти його, ми повинні мислити категоріями сучасного Сократу часу.

\title{
Література:
}

1. Платон. Апологія Сократа. Діалоги / Платон - Харків: Фоліо, 2008. $349 \mathrm{c}$.

2. Ясперс К. Сократ. История философии. 2003. № 10. С. 199-218.

DOI https://doi.org/10.30525/978-9934-26-148-0-6

\section{ВІТЧИЗНЯНА ЮРИДИЧНА НАУКА: ПРОБЛЕМИ ТА ВИКЛИКИ СУЧАСНОСТІ}

\section{Карпічков В. О.}

кандидат юридичних наук, дочент кафедри теорії та історії права та держави Інституту права Київького національного університету

\author{
імені Тараса Шевченка
}

м. Київ, Украӥна

Динамічний характер сучасного життя та суперечливі суспільні реалії ставлять перед вітчизняною юридичною наукою нові складні завдання. В технократичному суспільстві, де матеріальні цінності 